\title{
PENERAPAN PRINSIP AKUNTABILITAS PADA PEMBIAYAAN KEGIATAN EKSTRAKURIKULER KEAGAMAAN DI MADRASAH ALIYAH PARADIGMA PALEMBANG
}

\author{
${ }^{1}$ Nazarudin, ${ }^{2}$ Kris Setyaningsih, ${ }^{3}$ Masayu Nadya Ardelya Kesumah
}

${ }^{1}$ Universitas Islam Negeri (UIN) Raden Fatah Palembang

Jl. Prof. K. H. Zainal Abidin Fikri KM.3,5 Palembang Sumatera Selatan, 30126 Indonesia email: nazarudin_uin@radenfatah.ac.id

${ }^{2}$ Universitas Islam Negeri (UIN) Raden Fatah Palembang email: krissetyaningsi_uin@radenfatah.ac.id

${ }^{3}$ Universitas Islam Negeri (UIN) Raden Fatah Palembang email: ${ }^{3}$ msynadyaakesuma@yahoo.com

\begin{abstract}
The purpose of this study is to analyze the application of the principle of accountability in the financing of religious extracurricular activities in the Madrasah Aliyah Paradigma Palembang and the factors that support and inhibit the application of the principle of accountability in the financing of religious extracurricular activities in the Madrasah Aliyah Paradigma Palembang. This type of research is field research with a descriptive qualitative approach. The informants of this research are the madrasa head, Madrasa deputy head, madrasa treasurer and religious extracurricular adviser. The data collection tools used were interviews, observation and documentation study. After the data is collected then it is analyzed using the Milies and Huberman approach. Activities in data analysis in this approach are: data reduction, data display, and conclusion drawing / verification. Based on the results of research and discussion, conclusions can be drawn, namely: Application of the Principle of Accountability in Financing Religious Extracurricular Activities in Madrasah Aliyah Paradigma Palembang has been going well. It is clear that transparency of education providers is open to receiving input and including various components in budget management. Meet clear performance standards in every activity that can serve as benchmarks in carrying out duties, functions and authority with a full sense of responsibility. Participation from all parties to create a conducive atmosphere for each other. Factors supporting the application of the principle of accountability are setting clear goals and objectives. Solid institutional structure. Establish a clear and directed policy. Planning that is realistic, detailed and in accordance with needs. The inhibiting factors are the limitations of research in obtaining other supporting data sources regarding the financing of extracurricular activities such as evidence of financial allocation / expenditure transactions and accountability reports.
\end{abstract}

Keywords: Accountability Principles, Funding and Extracurricular Activities for religious

\section{PENDAHULUAN}

Manajemen pembiayaan pendidikan merupakan segenap kegiatan yang berkenaan dengan penataan sumber, penggunaan, dan pertanggungjawaban dana pendidikan dilembaga pendidikan. Pembiayaan pendidikan adalah faktor penting dalam menjamin mutu dan kualitas proses pendidikan. Meskipun pembiayaan pendidikan bukan satu satunya faktor keberhasilan, tanpa adanya pembiayaan yang mencukupi maka pendidikan 
yang berkualitas hanya ada dalam angan-angan. ${ }^{1}$ Biaya pendidikan merupakan komponen masukan instrumental (instrument input) yang sangat penting dalam menyiapkan SDM melalui penyelenggaraan pendidikan disekolah. ${ }^{2}$

Biaya (cost) dalam pengertian ini memiliki cakupan yang luas, yakni semua jenis pengeluaran yang berkenaan dengan penyelenggaran pendidikan baik dalam bentuk uang maupun barang dan tenaga. ${ }^{3}$ Biaya merupakan suatu unsur yang menentukan dalam mekanismen pengaanggaran, penentuan biaya akan mempengaruhi tingkat efisiensi dan efektifitas kegiatan dalam suatu organisasi yang akan mencapai suatu tujuan tertentu. ${ }^{4}$

Biaya pendidikan merupakan salah satu komponen masukan instrumental (instrumental input) yang sangat penting dalam penyelenggaraan pendidikan di sekolah. Biaya pendidikan memiliki peranan yang sangat menentukan. Hampir tidak ada upaya pendidikan yang dapat mengabaikan peranan biaya. Sehingga dapat dikatakan bahwa tanpa biaya proses pendidikan disekolah tidak berjalan.

Dari definisi di atas pembiayaan pendidikan dapat diartikan sebagai keseluruhan pengeluaran yang harus dikeluarkan seorang siswa sebelum mengikuti proses pendidikan.

Secara konseptual, besarnya biaya yang digunakan dan kemampuan dalam penyediaan anggaran merupakan petunjuk kelayakan (feasibility) sebuah institusi persekolahan. Institusi pendidikan dan pelatihan harus mampu menggaransi bahwa setiap item kegiatan yang akan dilakukan dan didukung oleh kemampuan financial yang memadai. Menurut danim, pembiayaan pendidikan mencakup aspek antara lain: ${ }^{5}$

1) Pembelajaran Capital (capital expenditures), adalah pengeluaran lembaga pendidikan untuk mendapatkan asset-aset yang dibutuhkan seperti: tanah, bangunan atau peralatanperalatan berat yang bersifat mayor lainnya.

2) Pembelajaran rutin (current expenditures), adalah pengeluaran lembaga pendidikan yang berlangsung secara kontinu dan bersifat berulang-ulang untuk memperlancar operasi program akademik dan non akademik.

3) Pembelajaran pendidikan (educational expenditures) merupakan bagian dari pembelajaran pendidikan dan pembelajaran umum dari lembaga pendidikan yang terkait

\footnotetext{
${ }^{1}$ Mulyono, Konsep Pembiayaan Pendidikan (Ar-Ruzz Media, 2010).

${ }^{2}$ Ibid.

${ }^{3}$ Dedi Supriadi, "Satuan Biaya Pendidikan Dasar Dan Menengah, Bandung: PT," Remaja Rusda Karya (2004).

4 Syaiful Sagala, "Manajemen Berbasis Sekolah Dan Masyarakat," Strategi Memenangkan Persaingan Mutu (Jakarta: Rakasta Samasta) (2004).

${ }^{5}$ Manajemen Pembiayaan Pendidikan Konsep Matin, “Aplikasinya,” Jakarta Cet. I (2014).
} 
langsung dengan kepentingan pembelajaran dan kesejahteraan siswa.

4) Pembelajaran pendidikan dan umum (educational and general expenditures), merupakan pembelajaran rutin lembaga pendidikan yang bersifat mendukung kegiatan pendidikan dan pembelajaran penelitian dan pengembangan, penelitian-penelitian teroraganisasi serta pelayanan kepada masyarakat.

Berdasarlan pendapat di atas dapat dikemukakan bahwa pembiayaan dalam suatu pendidikan sangat penting, agar tercapainya proses pembelajaran yang inovatif, kreatif, aktif dan efektif serta menyenangkan bagi murid dan guru. Dengan biaya yang memadai serta mendukung proses belajar mengajar akan terselenggara dengan baik. Murid akan mendapakatkan fasilitas yang memadai begitu pula guru. Dengan pembiayaan yang mendukung semua fasilitas dan sarana prasarana disekolah mendukung sarana pembelajaran dilembaga tersebut, seperti laboratorium, ketersediaan bahan ajar dan belajar, lingkungan yang bersih dan nyaman dan fasilitas-fasilitas lain yang mendukung proses belajar mengajar di sekolah.

Untuk kepentingan di atas pemerintah mengeluarkan Program Bantuan Operasional Sekolah (BOS) yang dimulai sejak Juli 2005. Program Bantuan Operasional Sekolah merupakan upaya pemerintah untuk melaksanakan amanat dari Undang-Undang Dasar Negara RI tahun 1945 yang termuat dalam Pasal 31 ayat satu, dua, tiga dan empat. Ayat 1 berbunyi "Setiap warga negara berhak mendapatkan pendidikan". Ayat 2 "Setiap warga negara wajib mengikuti pendidikan dasar dan pemerintah wajib membiayainya". Ayat 3 "Pemerintah mengusahakan dan menyelenggarakan satu sistem pendidikan nasional, yang meningkatkan keimanan dan ketakwaan serta akhlak mulia dalam rangka mencerdaskan kehidupan bangsa yang diatur dengan undang- undang". Ayat 4 "Negara memprioritaskan anggaran pendidikan sekurang kurangnya 20\% dari anggaran pendapatan dan belanja negara serta dari anggaran pendapatan dan belanja daerah untuk memenuhi kebutuhan penyelenggaraan nasional. Banyak siswa kurang mampu dalam hal biaya untuk melanjutkan pendidikan, namun seringkali bantuan yang diberikan oleh pemerintah belum terlaksanakan dengan baik. Oleh karena itu agar program dana Bantuan Operasional Sekolah berjalan dengan efektif dan tepat sasaran maka sekolah atau madrasah wajib memberikan laporan pertanggungjawaban penggunaan dana secara rutin sesuai dengan 
waktu yang sudah ditentukan. Menurut Mulyasa, dalam implementasinya pertanggungjawaban dalam manajemen sekolah dilakukan setiap akhir tahun anggaran. ${ }^{6}$

Dalam sistem Manajemen Pembiayaan (keuangan), pertanggungjawaban merupakan salah satu kegiatan sangat vital ini merupakan bentuk akuntabilitas pengelolaan keuangan suatu lembaga, hal ini juga berlaku dalam konteks manajemen keuangan pendidikan. Sekolah dan atau madrasah dalam manajemen pembiayaan juga dituntut pertanggungjawabaan, hal ini sesuai dengan prinsip dasarnya yaitu sekolah dan atau madrasah merupakan lembaga sektor publik yang pengelolaan keuangannya harus dipertanggunjawabkan seakuntabel mungkin kepada publik yang dalam implementasinya pertanggungjawaban tersebut dilakukan setiap akhir tahun anggaran. ${ }^{7}$

Pertanggungjawaban (Akuntabilitas) itu sendiri merupakan proses pembuktian dan penentuan bahwa apa yang dilaksanakan sesuai dengan apa yang direncanakan, hal ini meliputi pertanggungjawaban penerimaan dana, penyimpanan dan pengeluaran dana sesuai dengan perencanaan (proposional), atau secara lebih rinci bisa ditegaskan bahwa, pertanggungjawaban keuangan lembaga pendidikan mencakup seluruh penerimaan hingga pengeluaran dana pendidikan yaitu yang berkaitan dengan pelaksanaan pembiayaan proses pendidikan apakah sesuai dengan perencanaan yang telah dibuat dan sejauh mana tingkat pencapaian tujuan yang telah ditetapkan sebelumnya. Hal ini juga sering diistilahkan dengan proses evaluasi.

Prinsip akuntabilitas berarti penggunanaan dana sekolah yang tersedia sesuai dengan perencanaan yang telah ditetapkan dan dapat dipertanggungjawabkan. Penggunaan dana dilakukan oleh pihak sekolah secara bertanggungjawab dan harus berdasarkan perencanaan yang telah ditetapkan serta peraturan yang berlaku. Pertanggungjawaban yang dilakukan tertuju pada masyarakat, orangtua siswa, dan pemerintah. Terdapat 3 pilar utama dalam membangun akuntabilitas yang baik antara lain:

1. Adanya transparansi para penyelenggara pendidikan, terbuka dalam menerima masukan dan mengikutsertakan berbagai komponen dalam pengelolaan sekolah.

2. Adanya standar kinerja yang jelas di setiap institusi pendidikan yang bisa menjadi tolak ukur dalam melaksanakan tugas, fungsi, dan wewenang dengan penuh rasa tanggungjawab.

3. Adanya partisipasi dari semua pihak untuk saling menciptakan suasana yang kondusif

${ }^{6}$ E Mulyasa, "Manajemen Berbasis Sekolah, Cet," V, Bandung: PT Remaja Rosda Karya (2003).

${ }^{7}$ Ibid. 
agar pelayanan sekolah kepada masyarakat sesuai dengan prosedur, mudah, cepat dan murah. ${ }^{8}$

Akuntabilitas (accountability) yaitu berfungsinya seluruh komponen penggerak jalannya kegiatan perusahaan, sesuai tugas dan kewenangannya masing-masing. ${ }^{9}$ Akuntabilitas merupakan kewajiban untuk memberikan pertanggungjawaban atau untuk menjawab dan menerangkan kinerja dan tindakan seseorang/badan hukum/pimpinan kolektif suatu organisasi kepada pihak yang memiliki hak atau berwenang untuk meminta keterangan atau pertanggungjawaban. ${ }^{10}$

Sri Minarti menjelaskan bahwa, "Akuntabilitas adalah kondisi seseorang yang dinilai oleh orang lain karena kualitas performansinya dalam menyelesaikan tugas untuk mencapai tujuan yang menjadi tanggung jawabnya". ${ }^{11}$

Mulyasa mengemukakan akuntabilitas adalah, pertanggungjawaban pengelolaan keuangan sekolah dalam implementasi manajemen berbasis sekolah dituntut untuk memberikan pertanggungjawaban pada setiap akhir anggaran sekolah dengan dikeluarkannya dana selama tahun anggaran. Pertanggungjawaban tersebut dilaksanakan dalam rapat dewan sekolah, yang diikuti oleh komponen sekolah, masyarakat, dan pemerintah daerah. ${ }^{12}$

Miriam Budiarjo dalam Sutedi menjelaskan bahwa, "Akuntabilitas sebagai pertanggungjawaban pihak yang diberi mandat untuk memerintah kepada mereka yang memberi mandat itu."13

Dari beberapa pemaparan ahli di atas, maka dapat dikemukakan bahwa akuntabilitas di dalam manajemen keuangan berarti penggunaan uang sekolah yang dapat dipertanggungjawabkan sesuai dengan rencana yang telah dibuat dan dilaporkan kepada pemerintah, orang tua, dan masyarakat.

${ }^{8}$ Arwildayanto Arwildayanto, Lamatenggo Nina, and Tuna Sumar Warni, "Manajemen Keuangan Dan Pembiayaan Pendidikan" (Widya Padjadjaran, 2017).

${ }^{9}$ Suherman Toha, Penelitian Masalah Hukum Tentang Penerapan Good Corporate Governance Pada Dunia Usaha (Badan Pembinaan Hukum Nasional, Departemen Hukum dan Hak Asasi Manusia RI, 2007).

${ }^{10}$ Edy Sukarno, "Sistem Pengendalian Manajemen: Suatu Pendekatan Praktis," Jakarta: Gramedia Pustaka Umum (2002).

${ }^{11}$ Sri Minarti, "Manajemen Sekolah: Mengelola Lembaga Pendidikan Secara Mandiri," Yogyakarta: Ar-Ruzz Media (2011).

12 Mulyasa, "Manajemen Berbasis Sekolah, Cet."

13 Adrian Sutedi, Implikasi Hukum Atas Sumber Pembiayaan Daerah Dalam Kerangka Otonomi Daerah (Sinar Grafika, 2009). 
Salah satu lembaga pendidikan yang tetap eksis berkat dana BOS adalah Madrasah Aliyah Paradigma. Sebagai lembaga pendidikan yang mendukung program sekolah gratis dana BOS menjadi satu-satunyo sumber pendanaan di madrasah ini. Pertanyaannya adalah apakah sekolah kecil yang hanya memiliki 3 (tiga) rombongan belajar ini dapat melaksanakan kegiatan belajar mengajarnya termasuk kegiatan kstrakurikulier sesuai dengan prosedur yang ada. Kemudian bagaimanakah penerapan prinsip akuntabilitas pada pembiayaan kegiatan ekstrakulikuler keagamaan di Madrasah Aliyah Paradigma Palembang dan faktor apakah yang menjadi pendukung dan penghambat penerapan prinsip akuntabilitas pada pembiayaan kegiatan ekstrakulikuler keagamaan di Madrasah Aliyah Paradigma Palembang.

Penelitian ini dilakukan berangkat dari keinginan menjawab pertanyaanpertanyuaan di atas secara objektif dengan harapan dapat menjadi bahan pertimbangan bagi kepala sekolah, guru, pemerintah dan instansi yang terkait dalam merencanakan pembiayaan pendidikan.

\section{METODE}

Penelitian ini mengambil lokasi di Madrasah Aliyah Paradigma Palembang tahun ajaran 2019/2020. Jenis penelitian ini adalah penelitian lapangan (Field Research) dengan pendekatan deskriptif akualitatif. Informan penelitian ini adalah kepala madrasah, bendahara madrasah dan pembina ekstra kurikuler keagamaan. Adapun alat pengumpul data yang digunakan adalah wawancara, observasi dan studi dokumentasi. Setelah data terkumpul kemudian dianalisis dengan menggunakan pendekatan Milies and Huberman. Aktivitas dalam analisis data dalam pendekatan ini adalah: data reduction, data display, dan conclusion drawing/verification. ${ }^{14}$

\section{HASIL DAN PEMBAHASAN}

\section{Prinsip Akuntabilitas}

Prinsip akuntabilitas yang pertama yang harus dipenuhi oleh sekolah/madrasah adalah proses pembuatan keputusan itu sendiri.m Pembuatan sebuah keputusan harus dibuat secara tertulis dan tersedia bagi setiap warga yang membutuhkan. Madrasah Aliyah Paradigma dalam menentukan sasaran yang ditetapkan diperoleh berdasarkan analisis SWOT dan analisis kebutuhan pendidikan saat ini dan satu tahun kedepan”. Hal tersebut

14 Sugiyono, Metode Penelitian Pendidikan:(Pendekatan Kuantitatif, Kualitatif Dan $R$ \& D) (Alfabeta, 2008). 
dilakukan sekolah untuk menentukan skala prioritas program/kegiatan sehingga perencanaan sesuai dengan hasil pelaksanaan dan sebagai bahan evaluasi yang dapat dijadikan acuan dalam pengambilan keputusan. Kemudian untuk menetapkan program atau kegiatan prioritas yang perlu dilaksanakan diambil berdasarkan rapat dewan guru.

Prinsip akuntabilitas yang kedua yang harus dipenuhi oleh sekolah/madrasah adalah pembuatan keputusan memenuhi standar etika dan nilai-nilai yang berlaku. Tujuan akuntabilitas adalah dapat menentukan sasaran yang tepat, memanfaatkan pengelolaan dana selektif mungkin dan dapat dipertanggungjawabkan atas tujuan dari program tersebut. Di MA Paradigma dalam menentukan anggaran disesuaikan dengan tujuan kegiatan yang akan dilaksanakan. Pengunaan anggaran kegiatan ekstrakurikuler harus sesuai dengan rencana (RKAS) yang telah dibuat sebelumnya.

Prinsip akuntabilitas yang ketiga yang harus dipenuhi oleh sekolah/madrasah adalah adanya kejelasan dari sasaran kebijakan yang diambil dan sudah sesuai dengan visi, misi organisasi, serta standar yang berlaku.

Rencana kegiatan dana anggaran sekolah (RKAS) dibuat sesuai dengan visi, misi sekolah yang ada. Terkait dengan pembuatan anggaran yang disesuaikan dengan visi, misi sekolah. Salah satu point misi MA Paradigma adlah mengembangkan kecerdasan spiritual. Adanya anggaran untuk meningkatkan kualitas baca al-qur'an siswa, anggaran pelatihan al-qur'an untuk guru. Dan menciptakan siswa berwawasan internasional dengan adanya anggaran untuk pembelajaran Bahasa inggris, pelatihan, penggunaan buku, dan media yang mendukung semuanya untuk memenuhi misi ini.

Senada dengan pernyataan di atas, wakil kepala bidang kurikulum juga mengatakan bahwa MA Paradigma terkait dengan pembuatan anggaran kegiatan ekstrakurikuler disesuaikan dengan visi, misi sekolah. contohnya, membentuk akhlak yang baik, anggaran kegiatan ekstrakurikuler yang dikeluarkan harus mendukung sesuai dengan kebutuhan ekstrakurikuler dan media belajarnya. Setiap kegiatan mengacu pada visi, misi sekolah. Contohnya saja, visi cerdas dan berakhlak mulia, maka dari itu dibuatlah kegiataan keagamaan seperti pesantren Ramadhan.

Dari pemaparan kepala sekolah, wakil kurikulum dan bendahara sekolah dapat disimpulkan bahwa MA Paradigma membuat rencana kegiatan berdasarkan visi dan misi yang telah dibuat oleh sekolah. MA Paradigma telah menerapkan prinsip akuntabilitas dalam mengelolaan keuangan. Hal tersebut dapat dilihat dari setiap program kegiatan 
sekolah yang dilaksanakan, selalu mengarah kepada visi dan misi sekolah. Sehingga setiap program yang dilaksanakan, memiliki manfaat untuk siswa dan anggaran yang dikeluarkan dapat efektif dan efisien.

Dokumentasi dan informasi dalam pengelolaan anggaran disekolah sudah diterapkan oleh MA Paradigma yaitu dengan adanya pembuatan RKAS dalam perencanaan anggaran sekolah, pembuatan proposal anggaran kegiatan, laporan pertanggungjawaban kegiatan yang disertai dengan bukti fisik. Sasaran kebijakan dalam pengelolaan keuangan di sekolah sangat penting, yaitu untuk menetapkan tujuan dan hal yang paling penting untuk dilaksanakan. Setelah penetapan sasaran kebijakan tercapai, maka sekolah harus menilai kebijakan tersebut apakah sudah sesuai dengan hasil yang diharapakn. Tolak ukur dalam menilai sasaran kebijakan anggaran di MA Pardigma, yaitu dengan melihat anggaran yang disampaikan oleh sekolah MA Paradigma.

Prinsip akuntabilitas memberikan pertanggungjawaban yang harus disampaikan oleh para pemangku kepentingan. Segala kebijakan dan informasi dalam kebijakan pengelolaan keuangan dana kegiatan ekstrakurikuler, MA Paradigma melakukan penyebaran informasi melalui surat yang diberikan kepada orangtua siswa.

Prinsip akuntabilitas yang keempat yang harus dipenuhi oleh sekolah/madrasah adalah adanya mekanisme untuk menjamin bahwa standar telah terpenuhi dengan konsekuensi pertanggungjawaban, jika standar tersebut tidak terpenuhi.

Dari hasil informasi mengenai kebijakan pengelolaan keuangan disekolah, tentunya ada saja hal yang menjadi keluhan atau permasalahan yang dirasakan oleh pemangku kepentingan, sekolah harus dapat menampung dan memberikan solusi dari setiap permasalahan yang terjadi. Hal tersebut di jelaskan oleh wakil kurikulum sekolah, bahwa adanya pengaduan dari guru ataupun orangtua siswa disampaikan dan diselesaikan dalam rapat serta mencara solusi. "Di MA Paradigma mekanisme pengaduan masyarakat dilakukan dengan cara disampaikan kepada Kepala Sekolah melalui rapat”.

Prinsip akuntabilitas yang kelima yang harus dipenuhi oleh sekolah/madrasah adalah konsistensi maupun kelayakan dari target operasional yang telah ditetapkan maupun prioritas dalam mencapai target tersebut.

Di MA Paradigma melakukan program dan kegiatan sesuai dengan yang direncanakan, tidak ada realisasi yang tidak sesuai program yang telah direncanakan. Dengan demikian MA Paradigma sudah memenuhi prinsip akuntabilits yang kelima yakni 
konsistensi maupun kelayakan dari target operasional yang telah ditetapkan maupun prioritas dalam mencapai target tersebut.

Dapat disimpulkan bahwa penerapan prinsip akuntabilitas pada pembiayaan kegiatan ekstrakurikuler kepada stakeholders di MA Paradigma sudah cukup baik, yaitu dengan adanya pembuatan dokumentasi dari setiap hasil anggaran kegiatan ekstrakurikuler, pemberian informasi kepada para pemangku kepentingan mengenai informasi kebijakan anggaran sekolah, adanya sasaran kebijakan yang telah dijalankan sesuai dengan visi, misi dan tujuan sekolah serta penilaian atau evaluasi dari setiap anggaran kegiatan ekstrakurikuler yang dilakukan sebagai bahan pertimbangan dan pengambilan keputusan. Evaluasi Keuangan Sekolah, Evaluasi merupakan proses penilaian dalam pencapaian tujuan, artinya menilai pelaksanaan proses pengelolaan keuangan yang terjadi di sekolah, menilai pencapaian sasaran program, dan membuat rekomendasi untuk perbaikan anggaran yang akan datang.

Hal tersebut di jelaskan oleh Waka Bid. Kurikulum, bahwa adanya pengaduan dari guru ataupun orangtua siswa disampaikan dan diselesaikan dalam rapat serta mencari solusi "Pada tahap evaluasi anggaran, sekolah membuat laporan keuangan untuk dinilai dan dipertanggungjawabkan keada pihak yang berkepentingan”.

Dengan adanya laporan keuangan sebagai pertanggungjawaban sekolah kepada yayasan, pihak sekolah harus memiliki sistem informasi manajemen dan memonitoring hasil yang telah dicapai. Sistem informasi manajemen tersebut berupa laporan keuangan dalam memberikan hasil evaluasi anggaran. Hal tersebut senada dengan penjelasan Bendahara Sekolah, beliau mengatakan bahwa: "dengan adanya SOP, proses mendapatkan dana, penggunaan dana kegiatan ekstrakurikuler disitu menjadi bahan pengambilan keputusan". ... dengan adanya laporan keuangan sebagai bahan evaluasi anggaran kegiatan ekstrakurikuler sekolah yang diketahui oleh pihak internal saja dan sebagai bahan pengambilan keputusan.”

Sedangkan monitoring terhadap hasil pengelolaan anggaran dilakukan oleh pihak yayasan dan manajemen sekolah terhadap laporan keuangan setiap satu tahun. Laporan keuangan sekolah terdiri dari neraca, laba rugi, perubahan equitas, perubahan arus kas, analisa laporan keuangan, catatan atas laporan keuangan, dan daftar aktiva tetap. Serta laporan pertanggungjawaban sekolah yang dilakukan setiap bulan. Dan monitoring penggunaan dana BOS disampaikan setiap triwulan untuk dana BOS Pusat dan BOS Kabupaten/Kota, serta dana BOS Provinsi dilaporkan per semester. 


\section{Transparansi}

Transparansi merupakan prinsip yang menjamin akses atau kebebasan bagi setiap orang untuk memperoleh infromasi. Informasi mengenai keterbukaan dalam pengelolaan keuangan sekolah, merupakan salah satu prinsip yang harus dilakukan oleh pihak sekolah dalam menjalankan undang-undang sistem pendidikan nasional tentang pengelolaan dana pendidikan. Pengelolaan dana pendidikan dilaksanakan berdasarkan prinsip keadilan, efesiensi, transparansi dan akuntabilitas public. Transparansi dalam pengelolaan keuangan disekolah sangat dibutuhkan dalam rangka meningkatkan kepercayaan orangtua siswa, masyarakat, dan pemerintah.

Untuk mengetahui penerapan prinsip transparansi dalam pengelolaan keuangan kegiatan ekstrakurikuler di MA Paradigma, peneliti melakukan metode wawancara dan studi dokumen dalam menggali informasi yang berkaitan. Informasi ini didapatkan dari informan yang terlibat langsung dalam pengelolaan keuangan kegiatan ekstrakurikuler sekolah yaitu, Kepala Madrasah, Bendahara Sekolah, dan Wakil Kurikulum Sekolah. Wawancara juga dilakukan kepada infroman untuk mengkonfirmasi dengan program/kegiatan sekolah dalam merencanakan dan melaksanakan.

Dalam melaksanakan penerapan prinsip akuntabilitas pada pembiayaan kegiatan ekstrakurikuler keagamaan di sekolah dalam pengelolaan keuangan di MA Paradigma telah memiliki SOP tentang pengelolaan keuangan, namun SOP pengelolaan keuangan tersebut masih bersifat internal. Dari studi dokumen mengenai SOP, peneliti hanya dapat meringkas tentang sub bab SOP, yaitu a) sistem penganggaran, b) sistem penerimaan, c) sistem pengelolaaan bon sementara, d) prosedur pengelolaan hutang dan piutang, e) sistem pembayaran biaya personil, f) prosedur pengadaan barang dan jasa, g) sistem pengelolaan kas kecil (perry cash). Didalam SOP tersebut juga terdapat tabel yang menjelaskkan uraian prosedur, pelaksana, dan dokumen yang digunakan dalam melaksanakan kegiatan anggaran kegiatan ekstrakurikuler.

Penerapan prinsip transparansi bertujuan untuk membangun kepercayaan semua pihak dari rencana anggaran kegiatan ekstrakurikuler yang dilaksanakan. MA Paradigma membangun kepercayaan stakeholders dengan memberikan keterbukaan informasi dalam proses perencanaan kegiatan siswa setiap tahunnya, tentunya dengan memberikan informasi anggaran yang harus dibayarkan siswa pertahun. Hal tersebut sesuai dengan penuturan Kepala Sekolah MA Paradigma, bahwa keterbukaan dalam proses perencanaan anggaran kegiatan ekstrakurikuler sekolah yaitu : MA Paradigma terbuka terhadap 
stakeholders, yaitu melibatkan tim manajemen dan yayasan dalam merencanakan biaya pendidikan peserta didik dalam satu tahun ajaran, guru dan karyawan mengajukan kebutuhan selama satu tahun dan membuat dafatr ususlan anggaran kegiatan ekstrakurikuler, dan komite sekolah dalam merencanakan anggaran dana komite sesuai dengan kebutuhan kegiatan siswa. Kalau stakeholders eksternal, yaitu pemerintah hanya sebatas dana BOS yang perencanaannya dilakukan dalam 3 bulan sekali.

Sedangkan keterbukaan dalam proses pelaksanaan anggaran kegiatan di MA Paradigma, dijelaskan oleh Bendahara Sekolah bahwa: secara langsung melibatkan guru, karyawan dan komite sekolah. mereka melaksanakan anggaran kegiatan ekstrakurikuler yang telah diusulkan kepada atasan, membelanjakan anggaran tersebut sesuai dengan kebutuhan kegiatan ekstrakurikuler keagamaan dan membuat laporan pertanggungjawaban disertai kuitansi atau bukti fisik.

Keterbukaan yang dilakukan oleh MA Paradigma dalam proses perencanaan dan pelaksanaan dimaksudkan, untuk memberikan informasi anggaran dana yang akan dilaksanakan selama satu tahun ajaran. Sehingga memberikan pemahaman kepada guru, karyawan, dan orang tua siswa serta saling bekerja sama dalam melaksanakan kegiatan ekstrakurikuler sekolah sesuai dengan tujuan yang telah ditentukan. MA Paradigma hanya mempunyai auditor internal, seperti yang diungkapkan oleh bapak Mgs. Nazarudin, bahwa MA Paradigma memiliki audit internal saja. Biasanya audit dilakukan pada bulan Maret, proses dalam mengaudit laporan keuangan, yaitu tim audit melihat laporan keuangan dan mewawancarai pihak yang terlibat dalam pengelolaan keuangan kegiatan, yaitu direktur dan kepala keuangan dan pihak yang menerima hasil audit keuangan adalah yayasan.

Manfaat penting dari adanya transparansi anggaran kegiatan ini, ialah meningkatnya kepercayaan terhadap komitmen lembaga untuk memutuskan kebijakan tertentu. Di MA Paradigma kebijakan anggaran yang dikeluarkan adalah biaya kenaikan gaji guru dan karyawan. Hal tersebut sesuai dengan penuturan kepala sekolah bahwa kebijakan anggaran kegiatan ekstrakurikuler sekolah yang diumumkan kepada stakeholders mengenai: "dalam rapat rutin guru dan karyawan terkait pengajian atau keuangan kegiatan itu saja."

Kebijakan mengenai kenaikan gaji di MA Pardigma, dikarenakan adanya keputusan kenaikan gaji setiap tahunnya dari sekolah atau pengajuan kenaikan gaji yang dilakukan oleh guru dan karyawan dengan pertimbangan beban pekerjaan, inflasi dan kondisi kebutuhan ekonomi. 
Dalam proses penganggaran, keterlibatan stakeholders sangat diperlukan untuk belajar bertanggungjawab terhadap pilihan keputusan dan pelaksanaan kegiatan. MA Paradigma memberikan kesempatan kepada stakeholders untuk berpartisipasi dalam proses penganggaran, terkait dengan bentuk partisipasi stakeholders, Bapak Mawardi selaku Bendaha Sekolah mengatakan: "partisipasi dalam proses penganggaran bisa berbentuk keterlibatan langsung dalam proses penganggaran, usulan kegiatan, saran dan kritik yang membangun, dukungan moral dan materi."

Pemberian kesempatan kepada stakeholders untuk berpartisipasi dalam proses penganggaran disepakati oleh bidang Kurikulum yang berpendapat bahwa: “...partisipasi stakeholders berupa usulan dan saran yang disampaikan kesekolah baik dari guru dan orang tua mengenai kegiatan sekolah."

Senada dengan pendapat Raslaini Asmiyati selaku kepala MA Paradigma, bahwa pemberian partisipasi stakeholders dalam proses penganggaran. Beliau mengatakan: “... partisipasi guru dan karyawan, komite dalam bentuk pengajuan kebutuhan media/sumber belajar, operasional sekolah dan kebutuhan kegiatan siswa. Mereka mengajukan kebutuhan tersebut ke atasan dengan dana/anggaran yang dicantumkan. Setelah itu, mereka membuat proposal atau bon sementara untuk melakukan pembelian barang/jasa serta membuat laporan pertanggungjawaban atau menyerahkan struk pembayaran ke bagian keuangan."

Dari pendapat di atas dapat disimpulkan bahwa MA Paradigma telah memberikan kesempatan kepada stakeholders dalam proses anggaran dengan adanya keterlibatan guru, karyawan, dan orangtua dalam kebutuhan proses belajar mengajar dan kegiatan yang akan dilakukan sekolah. Dengan adanya partisipasi stakeholders dapat meningkatkan wawasan dan pengetahuan mereka dalam proses penganggaran serta meningkatkankepercayaan stakeholders kepada sekolah. Wawasan dan pengetahuan yang dididapat oleh stakeholders dijelaskan oleh Bendaha sekolah bahwa: “... mereka belajar mengenai peraturan keuangan, bagaimana cara membuat proposal yang dibutuhkan, kegiatan yang dilakukan sesuai dengan tujuan yang telah ditentukan sebelumnya." Selanjutnya penjelasan kepala madrasah mengatakan bahwa dengan adanya partisipasi stakeholders dapat meningkatkan wawasan dan pengetahuan terhadap pengelolaan keuangan. “..., misalnya dengan pengalaman guruguru dalam kegiatan fieldtrip, mereka tahu bahwa dana yang dibutuhkan besar, sehingga mereka dapat menyesuaikan anggaran dengan paket kegiatan yang akan dipilih.”

Hal tersebut dapat diartikan bahwa, peningkatan wawasan dan pengetahuan dengan adanya keterlibatan stakeholders dalam proses penganggaran, yaitu guru, karyawan, dan 
komite dapat menentukan anggaran sesuai dengan kebutuhan kegiatan ekstrakurikuler. Keterbukaan meningkatkan kepercayaan stakeholders dalam proses anggaran. Salah satu bentuk kepercayan itu adanya dukungan dan kepercayaan dari orangtua dalam mebantu dana kegiatan yang kurang dalam suautu kegiatan yang dilaksanakan sekolah.”

Kepercayaan tersebut tentunya sangat dibutuhkan oleh sekolah maupun stakeholders. Dari adanya kepercayaan stakeholders, sekolah dapat bekerja sama dan dapat meminimalisir tindak penyimpangan atau korupsi yang dilakukan oleh sekolah.

Penerapan prinsip transparansi di MA Paradigma kepada pemerintah dapat dilihat dengan adanya pembayaran pajak. MA Paradigma memiliki kewajiban membayar pajak kepada pemerintah, yaitu jenis pajak penghasilan atau PPh Pasal 21. Berdasarkan hasil wawancara dengan Bendahara MA Paradigma bahwa: "Pajak yang dibayarkan atau dipotong hanya untuk guru dan karyawan yang pendapatan atau gajinya diatas Rp. 3.000.000 di MA Pardigma membayar pajak tersebut melalui bank atau kantor POS paling lambat tanggal 10 dan melaporkan SPT (Surat Pemberitahuan) paling lambat tanggal 20 bulan berikutnya ke kantor pajak pratama Palembang."

Hal tersebut senada dengan informasi yang diberikan oleh Kepala MA Paradigma yang mengatakan: "pajak yang dibayarkan oleh sekolah adalah jenis pajak $\mathrm{PPh} 21$, yaitu pajak penghasilan dari gaji guru dan karyawan, disekolah tidak semua guru dan karyawan membayar pajak. Menurut aturan pemerintah hanya penghasilan Rp. 3.000.000 dapat dikenakan pajak."

Dengan adanya pembayaran pajak PPh 21 penghasilan, merupakan wujud keterbukaan sekolah kepada pemerintah mengenai pengelolaan keuangan yang dilaksanakan oleh sekolah. Penerapan prinsip transparansi dalam perencanaan dan pelaksanaan di MA Paradigma sudah berjalan cukup baik, dengan adanya kerangka kerja yang menjelaskan tugas dan tanggungjawab dari setiap pertanggungjawaban kegitan ekstrakurikuler. Dalam perencanaan dan pelaksanaan MA Paradigma memberikan informasi anggaran dana kegiatan ekstrakurikuler yang akan dilaksanakan selama satu tahun ajaran, untuk memberikan kepercayaan kepada para pemangku kepentingan khususnya pihak internal yaitu yayasan, MA Paradigma telah memilki audit internal. Keputusan anggaran untuk kenaikan gaji guru dan karyawan merupakan bentuk keterbukaan sekolah kepada stakeholders.

Dari hasil penelitian mengenai penerapan prinsip akuntabilitas pada pembiayaan kegiatan ekstrakurikuler keagamaan di MA Paradigma dapat disesuaikan dengan teori yang 
ada di bab sebelumnya, dimana keterbukaan secara sungguh-sungguh, menyeluruh dan memberi tempat bagi stakeholders dalam proses perencanaan keuangan. Keterlibatan stakeholders dalam mebuat RKAS merupakan bentuk partisipasi yang mencerminkan transparansi pengelolaan keuangan sekolah. Proses pembuatan RKAS merupakan usulan dari bawah atau bersifita botton up, proses tersebut memberikan kesempatan kepada guru dan karyawan untuk terlibat langsung dalam proses pembuatan rencana anggaran kegiatan ekstrakurikuler.

Dapat disimpulkan bahwa penerapan prinsip transparansi di MA Paradigma sudah cukup baik, yaitu adanya keterlibatan tim manajemen, yayasan, guru, kayaan, dan komite dalam perencanaan dan pelaksanaan anggaran kegiatan yang diusulkan kepada atasan, serta sesuai dengan standar operasional prosedur sekolah.

\section{Faktor pendukung dan penghambat Penerapan Prinsip Akuntabilitas}

Faktor yang menjadi pendukung penerapan prinsip akuntabilitas yaitu, 1) penetapan tujuan dan sasaran yang jelas baik untuk jangka pendek mauapun jangka menengah 2) struktur kelembagaan yang solid untuk mendorong terwujudnya sistem manajemen yang efektif dan efisienguna mencapai tujuan 3) penetapan kebijakan yang jelas dan terarah 4) perencanaan yang realistis, terinci dan sesuai dengan kebuthan 5) pelaksanaan kegiatan yang efektif dan efisien, transparan baik dalam pengadaan barang dan jasa, pengelola keuangan, inventaris, dan 6) sistem pencatatatan yang jelas,akurat dan sederhana.

Sedangkan untuk penghambat dalam penerapan prinsip akuntabilitas ialah adanya keterbatasan penelitian dalam mendapatkan sumber data pendukung lainnya mengenai pembiayaan kegiatan ekstrakurikuler seperti bukti-bukti dari transaksi alokasi/ pengeluaran keuangan, laporan pertanggungjawaban dan lain-lainnya. Dan penggunaan teknik wawancara yang penulis lakukan hanya bisa kepada tiga narasumber saja yaitu kepala madrasah, bendahara, wakil kurikulum. Sedangkan masih banyak pihak-pihak yang bersangkutan yang dapat dijadikan sebagai narasumber dari wawancara.

\section{KESIMPULAN}

Berdasarkan hasil penelitian dan pembahasan dapat diambil beberapa kesimpulan yaitu: Penerapan Prinsip Akuntabilitas pada Pembiayaan Kegiatan Ekstrakurikuler Keagamaan di Madrasah Aliyah Paradigma Palembang sudah berjalan dengan baik. Hal ini dibuktikan dengan indikator berikut ini, pertama adanya transparansi para penyelenggara pendidikan, terbuka dalam menerima masukan dan mengikutsertakan 
berbagai komponen dalam pengelolaan sekolah dari yayasan, tim manajemen sekolah, guru dan karyawan, serta komite termasuk dalam pelaksanaan dan evaluasi anggaran. Kedua adanya standar kinerja yang jelas di setiap institusi pendidikan yang bisa menjadi tolak ukur dalam melaksanakan tugas, fungsi, dan wewenang dengan penuh rasa tanggungjawab. Ketiga adanya partisipasi dari semua pihak untuk saling menciptakan suasana yang kondusif agar pelayanan sekolah kepada masyarakat sesuai dengan prosedur, mudah, cepat dan murah.

Faktor pendukung Penerapan Prinsip Akuntabilitas pada Pembiayaan Kegiatan Ekstrakurikuler Keagamaan di Madrasah Aliyah Paradigma ialah : Penetapan tujuan dan sasaran yang jelas baik; Struktur kelembagaan yang solid; Penetapan kebijakan yang jelas dan terarah; Perencanaan yang realistis, terinci dan sesuai dengan kebuthan; Pelaksanaan kegiatan yang efektif dan efisien, transparan baik dalam pengadaan barang dan jasa, pengelola keuangan, inventaris; dan Sistem pencatatatan yang jelas,akurat serta sederhana. Adapun faktor penghambat yaitu adanya keterbatasan penelitian dalam mendapatkan sumber data pendukung lainnya mengenai pembiayaan kegiatan ekstrakurikuler seperti bukti-bukti dari transaksi alokasi/pengeluaran keuangan, laporan pertanggungjawaban dan lain-lainnya.

\section{DAFTAR RUJUKAN}

Arwildayanto, Arwildayanto, Lamatenggo Nina, and Tuna Sumar Warni. "Manajemen Keuangan Dan Pembiayaan Pendidikan.” Widya Padjadjaran, 2017.

Matin, Manajemen Pembiayaan Pendidikan Konsep. “Aplikasinya.” Jakarta Cet. I (2014). Minarti, Sri. "Manajemen Sekolah: Mengelola Lembaga Pendidikan Secara Mandiri." Yogyakarta: Ar-Ruzz Media (2011).

Mulyasa, E. "Manajemen Berbasis Sekolah, Cet." V, Bandung: PT Remaja Rosda Karya (2003).

Mulyono. Konsep Pembiayaan Pendidikan. Ar-Ruzz Media, 2010.

Sagala, Syaiful. "Manajemen Berbasis Sekolah Dan Masyarakat.” Strategi Memenangkan Persaingan Mutu (Jakarta: Rakasta Samasta) (2004).

Sugiyono. Metode Penelitian Pendidikan:(Pendekatan Kuantitatif, Kualitatif Dan $R \& D)$. Alfabeta, 2008.

Sukarno, Edy. "Sistem Pengendalian Manajemen: Suatu Pendekatan Praktis." Jakarta: 
Gramedia Pustaka Umum (2002).

Supriadi, Dedi. "Satuan Biaya Pendidikan Dasar Dan Menengah, Bandung: PT." Remaja Rusda Karya (2004).

Sutedi, Adrian. Implikasi Hukum Atas Sumber Pembiayaan Daerah Dalam Kerangka Otonomi Daerah. Sinar Grafika, 2009.

Toha, Suherman. Penelitian Masalah Hukum Tentang Penerapan Good Corporate Governance Pada Dunia Usaha. Badan Pembinaan Hukum Nasional, Departemen Hukum dan Hak Asasi Manusia RI, 2007. 